\title{
Sugar Beet Artificial Seeds an Overview
}

\author{
Wessam M. Rslan* \\ Agricultural Genetic Engineering Research Institute; Agricultural Research \\ Center, Egypt. \\ *To whom correspondence should be addressed: wessam.rslan@ageri.sci.eg
}

Citation: Rslan W. M. (2018) Sugar beet artificial seeds an overview. Highlights in BioScience, Volume 1.Article ID 20181, dio:10.36462/ H.BioSci.20181

Received: March 22, 2018

Accepted: June 17, 2018

Published: June 26, 2018

Copyright:@ 2018 Rslan. This is an open access article distributed under the terms of the Creative Commons Attribution License, which permits unrestricted use, distribution, and reproduction in any medium, provided the original author and source are credited.

Data Availability Statement: All relevant data are within the paper

Funding: The authors have no support or funding to report.

\begin{abstract}
Artificial seed propagation of crops broadens the horizon of plant biotechnology and farming. The technology offers techniques for micropropagulated seed analogs such as axillary leaves, embryogenic calli, somatic embryos, apical shoot tips, and protocorm-like organs. Micropropagules are embedded in gelling medium and carboxyl methyl cellulose active coatings. A variety of plant species, such as mulberry, sandalwood, cardamom, banana, sugar beet, maize, and relative, have recorded encapsulation of micro shoots and somatic embryos and subsequent recovery of full plantlets. This knowledge has shown that artificial seed manufacturing is possibly helpful for the propagation of economically significant species ' inferior hybrids on a big scale. Artificial seed development can only succeed with effective upstream manufacturing of micropropagules and downstream germination procedures for an elevated proportion of plant regeneration as one of the significant value-added plant tissue culture goods. Different micropropagules were regarded for the manufacturing of artificial seeds; however, mostly favored were somatic embryos and axillary stem buds. As micropropagules, somatic embryos were used to create artificial seeds in a wide range of fruit and plant organisms, which include Daucus carota, Picea abies, Arachis hypogaea, Medicago sativa, Psidium guajava, and Vitis vinifera. The review illustrated the concept of synthetic seeds and encapsulation procedure of sugar beet.
\end{abstract}

Keywords: Artificial seed, plant biotechnology, embryogenic, sugar beet, micropropagulated. 


\section{Introduction}

Ara et al. (1) described artificial plants as synthetically encapsulated somatic embryos, shoot tips, axillary flowers or another meristematic tissue employed for seed sowing and capable of converting into whole plants under in vitro and in vivo circumstances and maintaining their potential even after storage. The first one to suggest and handle encapsulated somatic embryos was Murashige (2). He also noted to the transfer option and used it as natural plants. Reddy et al. (3) clarified that the cultivation of plants using artificial plants from somatic embryos or other vegetative propagules opens up new agricultural and forestry technologies. A variety of plant species synthetic seeds have been effectively researched in plant propagation.

\section{Encapsulating agents}

Kitto and Janick (4) discovered that the most appropriate medium for the encapsulation of somatic embryos was' Polyox,' water-soluble resin. Redenbaugh et al. (5) suggested that magnesium alginate should be the most appropriate to encapsulate somatic embryos in alfalfa, celery, cauliflower and rose. Artificial seed performance relies on the spatial, qualitative, quantitative availability of growth regulators and nutrients together with an ideal physical setting (6). Mariani (7) indicated that gibberellic acid (GA3) and saccharose had an adverse impact on eggplant germination of synthetic seeds. In the meantime Refouvelet et al . (8) used BA (5 mg / 1) + 1/2 MS + NAA (0.01 mg/1) to encapsulate Syringa vulgaris. Pattnaik and Chand (9) axillary buds, Murashige and Skoog (10) medium (MS) without hormones and MS + 6-benzyladenine (BA, 4.4 $\mu \mathrm{M}$ ) have been used as artificial endosperm in Morus species.

Saiprasad (11) revealed that sodium alginate would be the most widely recognized hydro-gel and was regularly used as a matrix for artificial plants due to its small toxicity, low price, rapid gellation and bio-compatibility. Many researchers noted that the introduction to the encapsulation solution of aquatic cyanobacterial samples (12), bactericides and activated carbon (13), pesticides, fertilizers, microorganisms (Rhizobia), mycorrhiza fungi (14), fungicides (15) can safeguard encapsulated propagules from microorganisms, decrease the discharge of toxic compounds and improve the germination ability of seeds.

\section{Encapsulation procedure}

The hydro-gel encapsulation technique established by (5) was the most suitable technique for producing synthetic seeds. In this technique, by combining with calcium free liquid MS medium, sodium alginate of varying levels (2 to 5 percent) was formed and then the explants were blended with the solution. Together with the sodium alginate solution, explants were sucked with a pipette and dropped into calcium chloride pool in which the ion exchange reaction happens and sodium ions were substituted by calcium ions comprising alginate beads. It is necessary to complete the entire method under aseptic circumstances. The capsule size relies on the pipette nozzle's inner diameter. The beads structure and size relies on sodium alginate quantity, calcium chloride solutions, and complexion duration. Redenbaugh (16) proposed using a multi nozzle pipette in this embryo stream through the internal pipette and the solution of the alginate flows via the exterior pipette.

\section{Artificial seeds germination and field planting}

Several researchers (17-20) recorded successful field cultivation and transformation of natural plants. The synthetic plants in the future, particularly for the extremely requested species (21), may be an option planting material intended for the forestry sector. Artificial plants would enable plant propagules to be planted directly into the greenhouse or field, circumventing many of the additional phases (21). Fujii et al. (22) discovered that the maturation of ABA somatic alfalfa embryos yielded an elevated soil transformation rate of $48 \%$ to $64 \%$. Adding fungicide to alginate beads avoids contamination and increases the sustainability of mulberry seeds in soil (23) when sown. Fujii et al. (24) revealed effective field planting with 23 percent crop transformation of alfalfa artificial plants obtained from calcium alginate embryoids.

Nieves et al. (25) revealed that artificial plant sugarcane crops were larger and had a lower diameter at eight months, but at 12 months these distinctions faded. No variations in all parameters assessed among both artificial seed-derived plants and plants based from the other two techniques (traditional and isolated plant techniques) were discovered with regard to sugar assessment and yield. Asmah et al. (21) and Ma et al. (26) recorded the efficient germination level in Acacia hybrid (73.3 to 100\%) and Pseudostellaria heterophylla (80\%). In Podophyllum peltatum, sugar beet and Stevia rebaudiana, Rizkalla et al. (27) and Nower (28) noted that crop development improved by adding mannitol and/or sorbitol to the medium.

\section{Types of synthetic seeds}

Two forms of synthetic seeds have been established, i.e. desiccated and hydrated synthetic plants, according to the current literature. The synthetic desiccated seeds were first launched either directly or encapsulated in polyox from somatic embryos, followed by their desiccation (29). 
Desiccation has been accomplished either linearly through chambers of decreasing relative humidity slowly over a period of one or two weeks or swiftly by leaving the petri dishes overnight on the bench at the laminar airflow room (30). The hydrated artificial seed technology was first developed by encapsulating Medicago sativa (16) hydrated somatic embryos. These artificial hydrated seeds are employed to create plant species that are recalcitrant and susceptible to desiccation in their somatic embryos. Hydrated artificial seeds are usually ready in a hydrogel capsule by encapsulating somatic embryos or other propagules. Several techniques for producing hydrated artificial seeds were investigated, mostly using calcium alginate encapsulation (16).

\section{The genetic stability of synthetic seeds}

Artificial seeds were commonly used in many plant species for micro-propagation. Molecular researches have began from the last decade to determine genetic stability of plantlets derived from synthetic seeds, but no changes have been revealed at the biochemical and/or molecular scales. Many studies (31) endorsed the prospective benefit of synthetic seeds for genetically identical to natural seeds. Gangopadhyay et al. (32) investigated the genetic structure of plantlets obtained from encapsulated Ananas comosus micro shoots using RAPD and ISSR technologies $(33,34)$. Bekheet (35) indicated that both plantlets obtained from encapsulated bulblets and usually in vitro were genetically comparable to those obtained from in vivo in Allium sativum.

Narula et al. (36) used RAPD assessment to explore in vitro plantlet genetic structure obtained from Dioscorea bulbifera encapsulated plant advice. Srivastava et al. (37) reported that the analysis of Cineraria maritana's RAPD patterns revealed a median ratio of resemblance of 0.944 , confirming the molecular consistency of crops extracted from encapsulated micro-shoots followed by six months of storage. Tabassum et al. (38) investigated the genetic consistency of synthetic seeds obtained from mother crops and somatic embryos and discovered similarity in Cucumis sativus using RAPD markers.

Mishra et al. (39) also studies the genetic consistency of crops obtained from encapsulated microshoots in Picrorhiza kurrooa using RAPD profile cluster analysis. Lata et al. (40) used ISSR and gas chromatography (GC) study of six significant cannabinoids to examine the genetic structure of synthetic seed based crops of Cannabis sativa and demonstrated homogeneity in the regrown clones and the mother plant. Shoot tips are by far the most genetically consistent, but in callus and protoplast culture there is a strong probability of genetic shift (41-43).

\section{References}

1. Ara H, Jaiswal U, Jaiswal VS. Germination and plantlet regeneration from encapsulated somatic embryos of mango (Mangifera indica L.). Plant Cell Rep. Springer; 1999;19(2):166-70.

2. Murashige T. Plant cell and organ cultures as horticultural practices. Symposium on Tissue Culture for Horticultural Purposes 78. 1977. p. 17-30.

3. Naga BLRI, Mangamoori LN, Subramanyam S. Identification and characterization of EST-SSRs in finger millet (Eleusine coracana (L.) Gaertn.). J Crop Sci Biotechnol. Springer; 2012;15(10):9-16.

4. Kitto SL, Janick J. Hardening treatments increase survival of synthetically-coated asexual embryos of carrot. J Amer Soc Hort Sci. Springer; $1985 ; 110(2): 283-6$.

5. Redenbaugh K, Paasch BD, Nichol JW, Kossler ME, Viss PR, Walker KA. Somatic seeds: encapsulation of asexual plant embryos. Bio/technology. Nature Publishing Group; 1986;4(9):797.

6. Senaratna T. Artificial seeds. Biotechnol Adv. Elsevier; 1992;10(3):379-92.

7. Mariani P. Eggplant somatic embryogenesis combined with synthetic seed technology. Capsicum Newslett. 1992;289-94.

8. Refouvelet E, Le Nours S, Tallon C, Daguin F. A new method for in vitro propagation of lilac (Syringa vulgaris L.): regrowth and storage conditions for axillary buds encapsulated in alginate beads, development of a preacclimatisation stage. Sci Hortic (Amsterdam). Elsevier; 1998;74(3):233-41.

9. Pattnaik S, Chand PK. Morphogenic response of the alginate-encapsulated axillary buds from in vitro shoot cultures of six mulberries. Plant Cell Tissue Organ Cult. Springer; 2000;60(3):177-85.

10. Murashige, Toshio and FS. A revised medium for rapid growth and bio assays with tobacco tissue cultures. Physiol Plant. 1962;15(3):473-97.

11. Saiprasad GVS. Artificial seeds and their applications. Resonance. Springer; 2001;6(5):39-47. 
12. Wake H, Akasaka A, Umetsu H, Ozeki Y, Shimomura $\mathrm{K}$, Matsunaga T. Enhanced germination of artificial seeds by marine cynobacterial extract. Appl Microbiol Biotechnol. Springer; 1992;36(5):684-8.

13. Ganapathi TR, Suprasanna P, Bapat VA, Rao PS. Propagation of banana through encapsulated shoot tips. Plant Cell Rep. Springer; 1992;11(11):571-5.

14. Tan TK, Loon WS, Khor E, Loh CS. Infection of Spathoglottis plicata (Orchidaceae) seeds by mycorrhizal fungus. Plant Cell Rep. Springer; 1998;18(1-2):14-9.

15. Antonietta GM, Micheli M, Pulcini L, Standardi A. Perspectives of the encapsulation technology in the nursery activity of Citrus. Caryologia. Taylor \& Francis; 2007;60(1-2):192-5.

16. Redenbaugh K. Synseeds: applications of synthetic seeds to crop improvement. CRC Press Inc.; 1993.

17. Datta KB, Kanjilal B, Sarker DD. Artificial seed technology: Development of a protocol in Geodorum densiflorum (Lam) Schltr.--An endangered orchid. Curr Sci. JSTOR; 1999;1142-5.

18. Mandal J, Pattnaik S, Chand PK. Alginate encapsulation of axillary buds of Ocimum americanum L.(hoary basil), O. Basilicum L.(sweet basil), O. Gratissimum L.(shrubby basil), and O. Sanctum. L.(sacred basil). Vitr Cell Dev Biol. Springer; 2000;36(4):287-92.

19. Anand Y, Bansal YK. Synthetic seeds: A novel approach of in vitro plantlet formation in vasaka (Adhatoda vasica Nees.). Plant Biotechnol. Japanese Society for Plant Cell and Molecular Biology; 2002;19(3):159-62.

20. Ikhlaq M, Hafiz IA, Micheli M, Ahmad T, Abbasi NA, Standardi A. In vitro storage of synthetic seeds: effect of different storage conditions and intervals on their conversion ability. African J Biotechnol. Academic Journals (Kenya); 2010;9(35).

21. Asmah HN, Hasnida HN, Zaimah NAN, Noraliza A, Salmi NN. Synthetic seed technology for encapsulation and regrowth of in vitro-derived Acacia hyrid shoot and axillary buds. African J Biotechnol. Academic Journals (Kenya); 2011;10(40):7820-4.
22. Fujii JA, Slade D, Redenbaugh K. Maturation and greenhouse planting of alfalfa artificial seeds. Vitr Cell Dev Biol. Springer; 1989;25(12):1179-82.

23. Bapat VA, Rao PS. In vivo growth of encapsulated axillary buds of mulberry (Morus indica L.). Plant Cell Tissue Organ Cult. Springer; 1990;20(1):69-70.

24. Fujii, Slade D, Aguirre-Rascon J, Redenbaugh K. Field planting of alfalfa artificial seeds. Vitr. Springer; 1992;28(2):73-80.

25. Nieves N, Zambrano Y, Tapia R, Cid M, Pina D, Castillo R. Field performance of artificial seed-derived sugarcane plants. Plant Cell Tissue Organ Cult. Springer; 2003;75(3):279-82.

26. Ma XM, Wu CF, Wang GR. Application of artificial seeds in rapid multiplication of Pseudostellaria heterophylla. African J Biotechnol. Academic Journals (Kenya); 2011;10(70):15744-8.

27. Rizkalla AA, Badr-Elden AM, Ottai ME-S, Nasr MI, Esmail MNM. Development of artificial seed technology and preservation in sugar beet. Sugar Tech. Springer; 2012;14(3):312-20.

28. Nower AA. In Vitro Propagation and Synthetic Seeds Production: An Efficient Methods for Stevia rebaudiana Bertoni. Sugar Tech. 2014;16(1):100-8.

29. Kitto SL, Janick J. Polyox as an artificial seed coat for asexual embryos. HortScience. 1982. p. 488.

30. Ara H, Jaiswal U, Jaiswal VS. Synthetic seed: prospects and limitations. Curr Sci. JSTOR; 2000;1438-44.

31. Nyende AB, Schittenhelm S, Mix-Wagner G, Greef JM. Yield and canopy development of field grown potato plants derived from synthetic seeds. Eur J Agron. 2005;22(2):175-84

32. Gangopadhyay G, Bandyopadhyay T, Poddar R, Gangopadhyay SB, Mukherjee KK. Encapsulation of pineapple micro shoots in alginate beads for temporary storage. Curr Sci. JSTOR; 2005;972-7.

33. Adawy SS, Mokhtar MM, Alsamman AM, Sakr MM. Development of annotated EST-SSR database in olive (Olea europaea). Int J Sci Res. 2015;4(9):1063-73. 
34. Mokhtar MM, Adawy SS, El-Assal SE-DS, Hussein EHA. Genic and Intergenic SSR Database Generation, SNPs Determination and Pathway Annotations, in Date Palm (Phoenix dactylifera L.). PLoS One. Public Library of Science; 2016;11(7):e0159268.

35. Bekheet SA. A synthetic seed method through encapsulation of in vitro proliferated bulblets of garlic (Allium sativum L.). Arab J Biotech. 2006;9:415-26.

36. Narula A, Kumar S, Srivastava PS. Genetic fidelity of in vitro regenerants, encapsulation of shoot tips and high diosgenin content in Dioscorea bulbifera L., a potential alternative source of diosgenin. Biotechnol Lett. Springer; 2007;29(4):623-9.

37. Srivastava V, Khan SA, Banerjee S. An evaluation of genetic fidelity of encapsulated microshoots of the medicinal plant: Cineraria maritima following six months of storage. Plant Cell, Tissue Organ Cult. Springer; 2009;99(2):193-8.

38. Tabassum B, Nasir IA, Farooq AM, Rehman Z, Latif Z, Husnain T. Viability assessment of in vitro produced synthetic seeds of cucumber. African J Biotechnol. Academic Journals (Kenya); 2010;9(42):7026-32.

39. Mishra J, Singh M, Palni LMS, Nandi SK. Assessment of genetic fidelity of encapsulated microshoots of Picrorhiza kurrooa. Plant Cell, Tissue Organ Cult. Springer; 2011;104(2):181-6.
40. Lata H, Moraes RM, Bertoni B, Pereira AMS. In vitro germplasm conservation of Podophyllum peltatum L. under slow growth conditions. Vitr Cell Dev Biol. Springer; 2010;46(1):22-7.

41. Lindsey K, Gallois P. Transformation of sugarbeet (Beta vulgaris) by Agrobacterium tumefaciens. J Exp Bot. Oxford University Press; 1990;41(5):529-36.

42. Hisano H, Kimoto Y, Hayakawa H, Takeichi J, Domae $\mathrm{T}$, Hashimoto R, et al. High frequency Agrobacteriummediated transformation and plant regeneration via direct shoot formation from leaf explants in Beta vulgaris and Beta maritima. Plant Cell Rep. Springer; 2004;22(12):910-8.

43. Krishna H, Alizadeh M, Singh D, Singh U, Chauhan N, Eftekhari M, et al. Somaclonal variations and their applications in horticultural crops improvement. 3 Biotech. Springer; 2016;6(1):54. 